\title{
Possible Impacts of COVID-19 on Foreign Communities in Turkey
}

\author{
Hikmet Iskender ${ }^{1 *}$ \\ 1* Istanbul Technical University, Disaster Management Institute, Disaster and Emergency Management Department, Istanbul, Turkey, (ORCID: 0000-0001-7442-3960), \\ iskender@itu.edu.tr
}

(International Conference on Design, Research and Development- 15 - 18 Aralık 2021)

(DOI: 10.31590/ejosat.1040349)

ATIF/REFERENCE: Iskender, H. (2021). Possible Impacts of COVID-19 on Foreign Communities in Turkey. European Journal of Science and Technology, (32), 241-247.

\begin{abstract}
At the start of the year 2020 humanity found itself facing a new pandemic that eventually impacted the whole world on various levels. Many countries are already facing difficulties as well as many marginalized groups in these countries. In the present research, attention is focused on the possible impacts of COVID-19 and vulnerabilities of foreign groups in Turkey, especially those who came from the Levant region and Egypt after 2011. The research applied a survey suggested by the World Health Organization office for the European Union, and used other observational tools such as official reports and media coverage to evaluate the situation of the target community. It was determined that the effects of COVID-19 on this group can be seen already and this research is very important in order to document these effects. It was concluded that a good portion of the foreign community was impacted heavily by the pandemic both socially and economically, and the possible methods that can be used in order to accelerate their recovery were noted.
\end{abstract}

Keywords: COVID-19, Pandemic, Foreign communities, Economic impacts, Social impacts

\section{COVID-19'un Türkiye'deki Yabancı Topluluklar Üzerindeki Olası Etkileri}

$\ddot{O} z$

2020 yılının başında insanlık, sonunda tüm dünyayı çeşitli düzeylerde etkileyen yeni bir salgınla karşı karşıya kaldı. Bu ülkelerdeki marjinal grupların yanı sıra genel olarak birçok ülke zaten salgının getirdiği zorluklarla karşı karşıya kalmıştır. Sunulan bu araştırmada, COVID-19'un olası yabancı gruplar üzerindeki etkilerine ve özellikle 2011'den sonra Levant bölgesinden ve Misır'dan gelen yabancı grupların Türkiye'deki savunmasızlıklarına odaklanılmıştır. Çalışmada, Dünya Sağlık Örgütü'nün Avrupa Birliği Ofisi tarafından önerilen bir anket uygulamış ve hedef topluluğun durumunun değerlendirilmesi için resmi raporlar ve medyada yer alan diğer gözlem araçları kullanılmıştır. COVID-19'un bu gruplar üzerindeki etkilerinin belgelenmesi için bu araştırmanın çok önemli olduğu söylenebilir. Yabancı bir toplumun önemli bir bölümünün pandemiden hem sosyal hem de ekonomik olarak yoğun bir şekilde etkilendiği ve iyileşmelerini hızlandırmak için kullanılabilecek olası yöntemler sunulmuştur.

Anahtar Kelimeler: COVID 19, Pandemi, Yabancı azınlıklar, Ekonomik etkiler, Sosyal etkiler

${ }^{*}$ Corresponding Author: iskender@,itu.edu.tr 


\section{Introduction}

In December $31^{\text {st }}, 2019$, the world woke up to news stating that there was a new "viral pneumonia" in Wuhan, People's Republic of China (PRC). The information was first released by the World Health Organization's (WHO) Country Office in PRC, which in turn took it from a media statement on the Wuhan Municipal Health Commission webpage. The country office then notified the International Health Regulations (IHR) focal point in the WHO Western Pacific Regional Office (WPRO). The WHO's Epidemic Intelligence open sources platform also noted the same "viral pneumonia" in Wuhan. From this point on, many governments started asking to be provided with more information about the situation. In the following hours, the situation started to gain higher risk potential, so the WHO activated the Incident Management Support Team (IMST) as part of its response and coordination efforts for the new unidentified "viral pneumonia" cases. The WHO also asked the PRC to provide more information on the situation. The PRC did not respond to WHO demands to provide information about the new cases of "viral pneumonia of unknown cause" until the $3^{\text {rd }}$ of Jan 2020. On the $5^{\text {th }}$ of Jan 2020, the WHO provided the member states with the information regarding the new event and called for extra precautions to reduce the risk of acute respiratory infections. It also issued its first Disease Outbreak News report, which provided technical information to scientists, public health communities, and the media. Four days later the Chinese authorities determined that the cause of the "viral pneumonia" was the novel coronavirus, and one week later, on the $11^{\text {th }}$ of Jan 2020, the Chinese media reported the first death saying that the cause of death was coronavirus. From this point on, the virus started spreading all around the world, with Thailand reporting the first case outside the PRC on the $13^{\text {th }}$ of Jan, then Japan on the $16^{\text {th }}$ of Jan 2020 (Muniyappa \& Gubbi, 2020). Moving to the $22^{\text {nd }}$ of Jan 2020, the WHO issued a statement suggesting that the novel coronavirus can be transmitted from human to human; however, it said that more investigation was required (Jiang et al., 2020; Yücesahin \& Sirkeci, 2020). On $4^{\text {th }}$ of April 2020, the WHO reported 1 million cases of COVID-19 worldwide, with a ten-fold increment in one month (Schuchat, 2020). The effects of this pandemic started to unfold with reports from health sectors in different countries stating that they were at "risk of being out of stock" of the necessary antiretroviral, adequate ventilators and hospital capacity and other medical equipment such as masks and protective equipment, and other life-saving medicines. The WHO stated that the COVID-19 pandemic will drag 180 into poverty and chronic hunger by the end of the year. According to the online dashboard, more than 300 thousand new cases occurred globally daily, and the number of confirmed cases since the beginning of the pandemic was more than 69 million, with the number of dead exceeding 1.5 million people by the $12^{\text {th }}$ of December 2020 (WHO report, $2020 \mathrm{a} \& \mathrm{~b}$ ).

\section{COVID-19 Pandemic Path in Turkey}

Since the appearance of the first cases of the coronavirus, Turkey started taking steps to deal with possible consequences. These first steps were in the form of establishing a scientific board called the Coronavirus Scientific Advisory Board on the $10^{\text {th }}$ of January 2020. It consists of 31 members from different fields such as infectious diseases, clinical microbiology, internal medicine and intensive care medicine, etc. The board helps by providing updates and establishing guidelines for treatments that are carried out by medical staff and also establishing appropriate measures to be followed by the public. On the $3^{\text {rd }}$ of February, the Turkish Government suspended all flights from China and cut all transportation routes to Iran. This decision was followed by more suspensions on flights coming from Italy, South Korea, and Iraq on $29^{\text {th }}$ of February 2020. Later in the year most flights were suspended as the situation started getting out of control. On $11^{\text {th }}$ of March 2020, the country saw the first case of Covid-19 which was almost three months after the first reported cases in China. This first reported case was the reason behind the extra measures taken later in the month, such as closing libraries, cafes, gyms, and suspending Friday prayers. One week after the first reported case on the $18^{\text {th }}$ of March 2020, Turkey reported the first death from coronavirus of a man aged 89 years. The first wave of the COVID-19 pandemic reached its climax by the middle of April, then the number of cases reduced from the beginning of May. By June, the bans on transportation, gathering areas, and travel from and to Turkey was lifted. Also, the number of cases maintained a moderate number of 2000 per day and the situation seemed to be back under control. Yet by November, the number of cases started to go up again marking the beginning of the second wave of the pandemic, with calls from the office of the Presidency and Health Ministry to the public to maintain measures in order to lower the number of cases. On the $17^{\text {th }}$ of November, a new curfew on the weekends was announced (Ahsan, 2020; Coskun, Yildirim \& Gunduz, 2021; Karatas \& Tagay, 2021).

\section{Analyzing the Impacts of COVID-19 Pandemic in Turkey}

Moving to the economic outlook for Turkey, the impacts of COVID-19 on Turkey's economy started unfolding by the first half of 2020, with deficit reaching US\$20 billion and GDP contracting by $10 \%$ year on year in the second quarter of the year 2020. The economy was expected to slowly rebound from this situation with GDP reaching a decline of only $3.8 \%$ by the end of the year. Inflation was expected to average $12 \%$ in 2020 , and poverty was expected to only moderately increase to $9 \%$ by the end of the year. This increase was driven by the negative income impact of COVID-19. Households that lost jobs or stopped actively seeking work were the worst affected.

\subsection{Reviewing the target group}

The group targeted in this research consists mainly of Syrians who came to Turkey after the year 2011 as students, refugees, immigrants, and business people. The group also includes other Arab communities from other countries such as Egyptians and Palestinians as well as people from countries such as Iran, and people from North African countries such as Morocco, Libya, and Algeria. These groups of people account for 3.5 and 5 million people according to official sources. They also have their own economic and social characteristics that set them apart from the rest of the countries and make them more vulnerable to the pandemic. For example, a large portion of Syrians in Turkey were heavily affected by the measures taken by the government to prevent the spread of COVID-19, such as the closure of cafes, factories, restaurants, and sewing workshops. Also, some others worked in daily earning businesses, meaning that any full or partial closure to limit the impacts of the pandemic on the country also limited their daily earnings as well, and left them more vulnerable to unemployment and poverty. As these people had a much more difficult time finding jobs with a decent salary even before the pandemic and this situation worsened after the 
pandemic, they also had a more difficult time finding housing with standards abiding by social distancing in case of infection, meaning that they are more vulnerable to infection than other people (Bostan, 2021; The World Bank report, 2021; UN Women report, 2021).

\subsection{Objective of the research}

In this research, the impacts on the target community, vulnerabilities, and perceptions about the COVID-19 pandemic were evaluated by conducting a survey, as recommended by the WHO regional office for EU.

\subsection{Data collection tool, survey sample and data analysis}

The research used a survey published by the WHO regional office for the EU. The survey consisted of 119 questions divided into 19 headings and takes approximately 15 to 20 minutes to finish. The data for the study were collected between December 18 and December 27, 2020.
The sample consisted of foreign citizens aged 18 years and over, who can speak either Arabic or English, and live in Turkey. The sample size was calculated to be at least 97 people with a $10 \%$ margin of error, $95 \%$ confidence level, population proportion of $50 \%$, and targeted population of 5 million people (Ac1kgoz \& Gunay, 2020; Yanarateş, 2020).

Due to the second wave of the COVID-19 pandemic, the increased measures taken to combat the high number of daily cases such as social distancing and lockdowns, and the high risks of getting infected, the research was only possible through the internet (Guner, Hasanoglu \& Aktas, 2020). The participants were reached through different social media platforms. During the research, 102 people participated in the survey.

The index was calculated by finding the average of each statement with Eq. 1:

Index $=\frac{\text { Sum of values entered by participants }}{\text { Total number of participant }}$ (Eq.1)
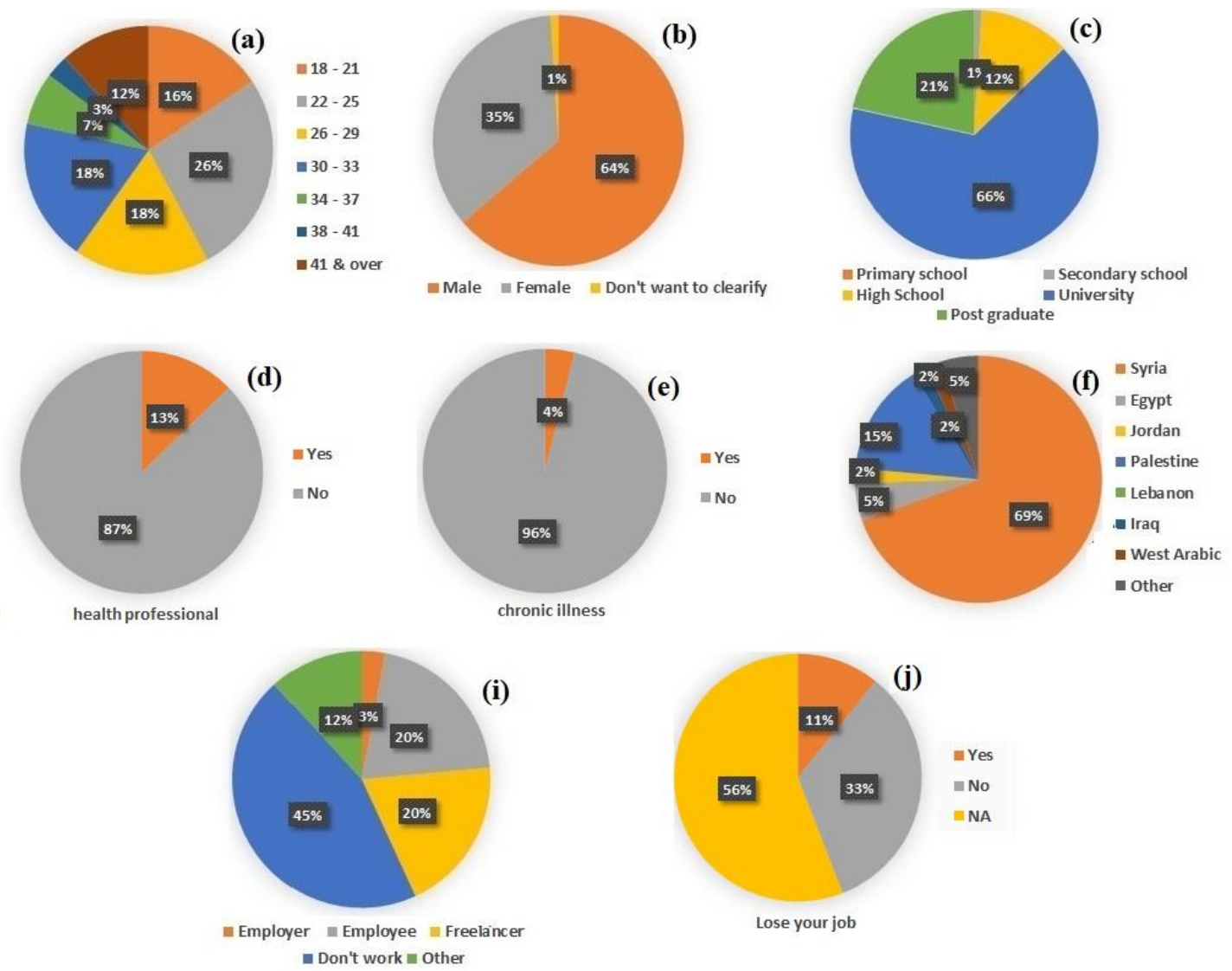

non't work = Othe

Figure 1. Details of survey 


\section{Results and Discussion}

The number of people who participated in the survey was 102 . The sample consisted of different age groups. However, more than half of participants were 30 years or younger, and $12 \%$ were people aged 41 years and older (Fig. 1a). The gender distribution of the sample was not ideal. Unfortunately, only $35 \%$ of the sample comprised females and $65 \%$ were males. This low level of representation by women may result in deviation from the true picture. Unfortunately, we attempted to balance the gender distribution towards $50 \%-50 \%$, but were faced with a low level of responses and sometimes rejections from females due to several reasons that were not possible to solve (Fig. 1b). The level of education for people who participated in the survey was high, more than $68 \%$ had a university degree, and only $12 \%$ said that they only had a high school degree (Fig. 1c). This level of education might reflect the awareness this group has, and how easy or difficult is to communicate with this group. This along with the low level of chronic illness reported in the sample gave us an understanding of how we should protect foreigners from the pandemic with the minimum economic and social damage, and it shows how much the targeted group was vulnerable to coronavirus (Fig. 1d\&e). They were from different countries but as predicted they were dominantly from Syria making up almost $70 \%$ of the sample, followed by Palestinians comprising $15 \%$ of the sample, Egyptians 5\%, and the rest were people from Iraq, North African countries, and Iran (Fig. 1f).

The types of job that the sample had showed the economic impact of the pandemic. More than $45 \%$ stated that they did not work even in pre-pandemic times (Fig. 1i). This reflected the nature of families in the target society; they consisted of one person who works (usually men). Also, this percentage indicated that many people were dependent on another person as a source of financial support, such as remittances coming from outside Turkey. A household with one salary for household members is more vulnerable to poverty, which occurred many times in 2020 due to the pandemic impact in Turkey. In addition, $11 \%$ of the people in the sample said they lost their jobs and only a few of them found another job later, as shown in Fig. 1j. Financially, the least affected people were freelancers, which made up $20 \%$ of the sample. The people affected most were employees, which also made up $20 \%$ of the sample, they did not only lose their jobs, they also had no social support because they were mostly unofficial workers. This claim was supported by the survey, which stated that more than $30 \%$ of the sample had the worst level in terms of financial situation.

The personal experience of individuals in the target group showed the spread of the COVID-19 pandemic among them. At least 1 out of 4 people participating in the survey was infected with the virus at some point during the last year. More than $90 \%$ of the sample knew people who were infected with the virus, and more than $50 \%$ of them knew people who passed away because of the virus.

Furthermore, most of the people who were infected reported that their infection was not severe and they did not need any medical attention. These findings indicate the dangerous nature of pandemics for foreign groups or communities. In foreign communities, usually, everyone knows and speaks the same language, has a social connection, and has an interest or economic relationship with everyone else within the same foreign community meaning that they tend to gather more often than citizens in the same country. This means that their vulnerability to e-ISSN: 2148-2683 the pandemic is much higher and as a result, more social impacts and more economic impacts are encountered. This is shown by the loss of jobs they experienced and the poor financial situation they reported.

The health awareness of people who participated in the sample was very high. In general, they reported that they had an easy time finding, understanding, and following the information, recommendations, and restrictions (Table 1).

Table 1. Health literacy of people participating in the study (value 1: very easy, value 7 : very difficult)

\begin{tabular}{lc}
\hline Questions & Index \\
\hline How easy or difficult would you say it is to very & 2.48 \\
easy find information you & \\
need related to Covid-19? & \\
How easy or difficult would you say it is to & 2.63 \\
understand the information you need related to & \\
Covid-19? & \\
How easy or difficult would you say it is to judge & 4.43 \\
if the information about Covid-19 in the media is & \\
reliable? & \\
How easy or difficult would you say it is to & 2.60 \\
understand restrictions and recommendations of & \\
authorities regarding Covid-19? & \\
How easy or difficult would you say it is to follow & 2.90 \\
the recommendations on how to protect yourself & \\
from Covid-19? & \\
How easy or difficult would you say it is to & 2.59 \\
understand recommendations about when to stay & \\
at home from work/school, and when not to? & \\
How easy or difficult would you say it is to follow & 2.82 \\
recommendations about when to stay at home \\
from work/school, and when not to?
\end{tabular}

However, they reported one issue that might impact their awareness which was difficulty in judging the information presented in the media. This awareness was combined with a high level of preparedness, which indicates that the people know how to protect themselves even though they tend to think it was difficult to avoid infection at the current level of the spread of the virus (Table 2). 
Table 2. Level of preparedness against COVID-19 of people participating in the study

\begin{tabular}{lc}
\hline Questions & Index \\
\hline $\begin{array}{l}\text { What do you consider to be your own probability of } \\
\text { getting infected with Covid-19? }\end{array}$ & 3.45 \\
$\begin{array}{l}\text { How susceptible do you consider yourself to } \\
\text { infection with Covid-19? }\end{array}$ & 3.82 \\
How severe would contracting Covid-19 be for you? & 4.20 \\
\hline
\end{tabular}

Preventive measures taken by the target people were also something asked about in the survey (Table 3 ). Washing hands, wearing a mask, ensuring social distancing, not using antibiotics to prevent COVID-19, and using disinfectants all had high index values, meaning that individuals within the target group tend to follow these prevention measures without any hesitation. What is concerning, on the other hand, is their lack of avoidance of social gatherings. Individuals in the target group had a difficult time avoiding gatherings as many of them were workers who would lose their livelihood if they were absent for even one day (Table 4). From the $5^{\text {th }}$ and $7^{\text {th }}$ questions, it can be seen that even though the index was tending toward "very much so" but by "just a little", meaning that there were still many individuals that were at risk because they did not avoid social gatherings. One other reason why they did not avoid social gatherings was their religious duty such as Friday prayer, but we do not believe this had a fundamental role in the larger context.

Table 3. Preventive measures taken against COVID-19 by people participating in the study (value 1: very much so, Value 7: not at all)

\begin{tabular}{lc}
\hline Questions & Index \\
\hline $\begin{array}{l}\text { Frequently wash my hands with soap and water for } \\
\text { at least } 20 \text { second }\end{array}$ & 2.75 \\
$\begin{array}{l}\text { Avoid touching my eyes, nose, and mouth with } \\
\text { unwashed hands }\end{array}$ & 2.86 \\
Use disinfectants to clean hands when soap and & \\
water were not available & 2.43 \\
Avoid a social event I wanted to attend & 3.14 \\
Avoid Friday prayer & 4.08 \\
Stay at home (Didn't go to work or school) & 3.33 \\
Use antibiotics to prevent or treat COVID-19 & 5.96 \\
Wear a mask in public & 1.38 \\
Ensure physical distancing in public & 2.40 \\
Disinfect surfaces & 2.99 \\
\hline
\end{tabular}

The effects of the pandemic on social behaviors, and well-being levels were observed in our survey. As students and people in general, were forced to stay at home, more and more of them reported difficulties they faced in education. The worst result of such difficulties was the erosion of human capital and the erosion of skills needed in order for individuals to be able to find a job or secure a salary. In addition, primary, middle, and high schools in Turkey converted to online education to protect them against any health consequences from the pandemic; however, this decision had other uncalculated consequences. These consequences were social ones as most families reported difficulties in raising their children and educating them. Not only that but also some parents quit their jobs in order to help their children with online education.
The uncertainties induced by the pandemic increased levels of stress and fear among foreign communities.

Table 4. Different effects of COVID-19 on people participating in the study

\begin{tabular}{|c|c|c|c|}
\hline Questions & Value of 1 & Value of 7 & Index \\
\hline & Far away & & \\
\hline & from me & Close to me & 4.20 \\
\hline & Spreading fast & $\begin{array}{l}\text { Spreading } \\
\text { slowly }\end{array}$ & 2.58 \\
\hline & A thing I & A thing I & \\
\hline & $\begin{array}{l}\text { never think } \\
\text { about it }\end{array}$ & $\begin{array}{l}\text { think about } \\
\text { it a lot }\end{array}$ & 3.97 \\
\hline & Not fear & Fear & \\
\hline & inducing & inducing & 4.75 \\
\hline & Not media & Media & \\
\hline & hyped & hyped & 4.07 \\
\hline & & Not & \\
\hline & Combatable & combatable & 3.60 \\
\hline & Not stressful & Stressful & 4.90 \\
\hline & $\begin{array}{l}\text { Makes the } \\
\text { home worse }\end{array}$ & $\begin{array}{l}\text { Doesn't } \\
\text { make the } \\
\text { home worse }\end{array}$ & 4.53 \\
\hline & $\begin{array}{l}\text { Dismantles } \\
\text { family } \\
\text { relations }\end{array}$ & $\begin{array}{l}\text { Doesn't } \\
\text { dismantle } \\
\text { family } \\
\text { relations }\end{array}$ & 4.79 \\
\hline & $\begin{array}{l}\text { Doesn't make } \\
\text { raising }\end{array}$ & $\begin{array}{l}\text { It makes } \\
\text { raising }\end{array}$ & \\
\hline \multirow[t]{10}{*}{ COVID-19 to me feels } & children more & children & 4.25 \\
\hline & $\begin{array}{l}\text { difficult } \\
\text { It doesn't }\end{array}$ & more difficult & \\
\hline & make & It makes & \\
\hline & educating & educating & \\
\hline & children more & children & 5.64 \\
\hline & difficult & more difficult & \\
\hline & Will not & & \\
\hline & $\begin{array}{l}\text { impact my } \\
\text { future }\end{array}$ & $\begin{array}{l}\text { Will impact } \\
\text { my future }\end{array}$ & 4.56 \\
\hline & Will impact & Will impact & \\
\hline & $\begin{array}{l}\text { my future } \\
\text { negatively }\end{array}$ & $\begin{array}{l}\text { my future } \\
\text { positively }\end{array}$ & 3.93 \\
\hline
\end{tabular}

This distortion in their life routine and social life impacted the well-being of people and their behaviors (Table 4). Other effects of the distortion of normal life were less exercise, not going to the doctor for a non-COVID-19 related problem, and eating less healthy food. But behaviors related to smoking, drinking, and ethnicity were at an all-time low (Table 5). 
Table 5. Level of acceptance of unwanted behavior.

\begin{tabular}{|c|c|c|c|}
\hline Questions & Yes & No & NA \\
\hline \multirow[t]{2}{*}{$\begin{array}{l}\text { Avoided people that I } \\
\text { thought might infect me, } \\
\text { based on their ethnicity }\end{array}$} & 6 & 61 & 35 \\
\hline & $5.88 \%$ & $59.80 \%$ & $34.31 \%$ \\
\hline \multirow[t]{2}{*}{$\begin{array}{l}\text { Exercised less than I did } \\
\text { before the pandemic }\end{array}$} & 41 & 39 & 22 \\
\hline & $40.20 \%$ & $38.24 \%$ & $21.56 \%$ \\
\hline \multirow[t]{2}{*}{$\begin{array}{l}\text { Drank more alcohol } \\
\text { than I did before the } \\
\text { pandemic }\end{array}$} & 4 & 32 & 66 \\
\hline & $3.92 \%$ & $31.37 \%$ & $64.70 \%$ \\
\hline \multirow[t]{2}{*}{$\begin{array}{l}\text { Ate more unhealthy } \\
\text { food than I did before } \\
\text { the pandemic }\end{array}$} & 29 & 55 & 18 \\
\hline & $28.43 \%$ & $53.92 \%$ & $17.64 \%$ \\
\hline \multirow[t]{2}{*}{$\begin{array}{l}\text { Smoked more than I did } \\
\text { before the pandemic }\end{array}$} & 11 & 36 & 55 \\
\hline & $10.78 \%$ & $35.29 \%$ & $53.92 \%$ \\
\hline \multirow[t]{2}{*}{$\begin{array}{l}\text { Postpone vaccination } \\
\text { for myself or my child }\end{array}$} & 4 & 29 & 69 \\
\hline & $3.92 \%$ & $28.43 \%$ & $67.65 \%$ \\
\hline \multirow[t]{2}{*}{$\begin{array}{l}\text { Avoided going to the } \\
\text { doctor for a non- } \\
\text { COVID-19-related } \\
\text { problem }\end{array}$} & 43 & 40 & 19 \\
\hline & $42.15 \%$ & $39.22 \%$ & 18.63 \\
\hline \multirow[t]{2}{*}{$\begin{array}{l}\text { Bought drugs that I } \\
\text { heard are good for } \\
\text { treating COVID-19 }\end{array}$} & 18 & 68 & 16 \\
\hline & $17.65 \%$ & $66.67 \%$ & $15.69 \%$ \\
\hline
\end{tabular}

\subsection{Resilience and Recovery}

The resilience shown in the survey was good enough for people to get through the pandemic. The people reported that they can bounce back to their normal life from stressful and bad events somehow easily despite the hard economic and social consequences they experienced during the pandemic. However, this resilience might take a little while as people tend to need a longer time for recovery. Much help can be delivered by institutions in Turkey to decrease the impacts and vulnerability and increase resilience. In our survey, we asked people what institutions they trusted the most, and the most trusted institutions were the Ministry of Health, the family doctor, place of worship, police, and hospitals. By utilizing these institutions, we can inform the people correctly about the measures they need to protect themselves, avoid the spread of misinformation, understand their situation, get the correct information about people who need help to recover after the pandemic, and channel help to them from other NGOs. However, while delivering help, we believe that the tools that we should use to inform the people about the measures or help should not be ignored. In our survey, we found that not all tools are trusted; for example, social media, celebrities, TV, and radio are among the least trusted sources of information whereas health workers and the national Covid-19 website were trusted more.

\section{Conclusion}

In our research, first the COVID-19 pandemic was introduced, how it started and expanded globally. A timeline was provided of the main events that happened during the pandemic. Then, the path of the pandemic in Turkey was explained and a timeline of the main events that happened as a consequence of the pandemic was given. Attempts were made to analyze the global situation and Turkey's situation in terms of social and economic impacts. After that, a survey about the effects of COVID-19 on the foreign community was completed. Then data that were obtained from the survey were analyzed and the results are presented as figures and tables based on the method explained in the data analysis section. Lastly, the results were reviewed and discussed. It was concluded that a good portion of the foreign community was impacted heavily by the pandemic both socially and economically.

\section{Acknowledgement}

The author thanks Mohammad Orabi for kind help with data collection.

\section{References}

Açıkgöz, Ö. \& Günay, A. (2020). The Early Impact of the Covid19 Pandemic on the Global and Turkish Economy. Turkish Journal of Medical Sciences, 520-526. Retrieved from https://dergipark.org.tr/tr/pub/tbtkmedical/issue/53865/72450 7

Ahsan, M.M. (2020). Strategic Decisions on Urban Built Environment to Pandemics in Turkey: Lessons From COVID19. Journal of Urban Management, 9(3), 281-285

Bostan, S., Erdem, R., Ozturk, Y.E. et al. (2020). The Effect of COVID-19 Pandemic on the Turkish Society. Electronic Journal of Genetic Medicine, 17(6), 1-8.DOI: https://doi.org/10.29333/ejgm/7944

Coskun, H., Yildirim, N. \& Gunduz S. (2021). The Spread of COVID-19 Virus Through Population Density and Wind in Turkey Cities. Science of Total Environment, 751, 141663. DOI: $10.1016 /$ j.scitotenv.2020.141663

Guner, R., Hasanoglu, I. \& Aktas, F. (2020). COVID-19: Prevention and Control Measures in Community. Turkish Journal of Medical Science, 50(SI-1), 571-577. DOI: $10.3906 /$ sag-2004-146

Jiang, S., Shi, Z., Shu, Y., et al. (2020). A Distinct Name is Needed for the New Coronavirus. Lancet, 395(10228), 949950. DOI: 10.1016/S0140-6736(20)30419-0

Karatas, Z. \& Tagay, O. (2021). The Relationships Between Resilience of The Adults Affected by the Covid Pandemic in Turkey and COVID-19 Fear, Meaning in Life, Life Satisfaction, Intolerance of Uncertainty and Hope. Perspective and Individul Differences, 172, 110592. DOI: 10.1016/j.paid.2020.110592

Muniyappa, R. \& Gubbi, S. (2020). COVID-19 Pandemic, Coronaviruses, and Diabetes Mellitus. American Journal of Physiology-Endocrinology and Metabolism, 318, E736E741. DOI: 10.1152/ajpendo.00124.2020

Schuchat, A. (2020). Public Health Response To The Initiation And Spread Of Pandemic COVID-19 in the United States. Morbidity and Mortality Weekly Report, 69(18), 551-556. 
The World Bank, Recent Economic Developments, https://www.worldbank.org/en/country/turkey/overview\#3, Accessed December, 232020.

UN Women (2020). The Economic and Social Impact of COVID19 on Women And Men. https://reliefweb.int/sites/reliefweb.int/files/resources/73989r apidgenderassessmentreportturkey.pdf (Accessed April 19, 2020).

World Health Organization (2020a). Situation Report-167. Coronavirus disease (COVID-19). June 07, 2020. https://www.who.int/docs/defaultsource/coronaviruse/situation-reports/20200707-covid-19sitrep-169.pdf?sfvrsn=c6c69c88_2. (Accessed September 3, 2020).

World Health Organization. Situation Report-176 (2020b). Coronavirus disease (COVID-19). https://www.who.int/docs/defaultsource/coronaviruse/situation-reports/20200714-covid-19sitrep 176.pdf?sfvrsn=d01ce263_2. (Accessed September 3, 2020).

Yanarateş, E. (2020). An Overall Evaluation of the Covid-19 Pandemic. Social Scientific Centered Issues, 2 (1), 24-33. Retrieved from https://dergipark.org.tr/tr/pub/ssci/issue/55156/752577

Yücesahin, M.M. \& Sirkeci, I. (2020). Coronavirus and Migration: Analysis of Human Mobility and the Spread of COVID-19. Migration Letter, 2, 379-398. DOI: https://doi.org/10.33182/ml.v17i2.935 